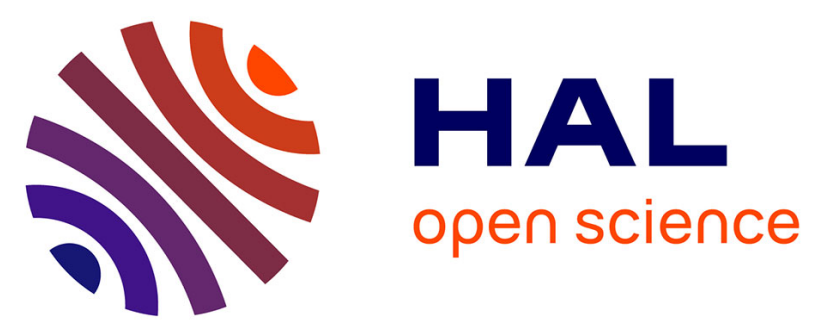

\title{
THE CORRELATION BETWEEN LAND AND SUBSOIL USE WHEN USING UNDERGROUND SPACE
}

T. Kharytonova, V. Nosik, Anatoliy Kostruba, V. Mykhailov, M. Kurilo

\section{- To cite this version:}

T. Kharytonova, V. Nosik, Anatoliy Kostruba, V. Mykhailov, M. Kurilo. THE CORRELATION BETWEEN LAND AND SUBSOIL USE WHEN USING UNDERGROUND SPACE. Vìsnik Kiïvs kogo nacìnal nogo unìversitetu ìmenì Tarasa Ševčenka, 2021, VISNYK TARAS SHEVCHENKO NATIONAL UNIVERSITY OF KYIV, 2(93), pp.64-70. 10.17721/1728-2713.93.07 . hal-03284994

\section{HAL Id: hal-03284994 \\ https://hal.science/hal-03284994}

Submitted on 13 Jul 2021

HAL is a multi-disciplinary open access archive for the deposit and dissemination of scientific research documents, whether they are published or not. The documents may come from teaching and research institutions in France or abroad, or from public or private research centers.
L'archive ouverte pluridisciplinaire HAL, est destinée au dépôt et à la diffusion de documents scientifiques de niveau recherche, publiés ou non, émanant des établissements d'enseignement et de recherche français ou étrangers, des laboratoires publics ou privés. 


\section{ISSN 1728-2713}

\section{UDC 504+550+551+552+624}

Published are the results of geological, stratigraphic, paleontological, hydrogeological, geophysical and geoinformation research.

For scientists, professors, graduate and postgraduate students.

Jornal is indexed in Web of Science, Academic Resource Index Research Bib and Google Scholar. Rank A of the Ministry of Education and Science of Ukraine.

Наведено результати геологічних, стратиграфічних, палеонтологічних, гідрогеологічних, геофізичних і геоінформаційних досліджень.

Для викладачів, наукових співробітників, аспірантів і студентів.

Видання індексується в науковометричних базах даних Web of Science, Academic Resource Index Research Bib та Google Scholar. Категорія А Міністерства освіти і науки України.

Приведены результаты геологических, стратиграфических, палеонтологических, гидрогеологических, геофизических и геоинформационных исследований.

Для преподавателей, научных сотрудников, аспирантов и студентов.

Издание индексируется в наукометрических базах данных Web of Science, Academic Resource Index Research Bib и Google Scholar. Категория A Министерства образования и науки Украины.

Chief publication manager 0 . Menshov

\section{EDITOR-IN-CHIEF \\ EDITORIAL BOARD}

Address

Approved by the

Certified by the

Certified by the

Founded and published by
V. Mykhailov, Dr. Sci. (Geol.), Prof.

Ukrainian Members:

I. Bezrodna, Cand. Sci. (Geol.), Senior Researcher (Deputy Editor-in-Chief); O. Menshov, Dr. Sci. (Geol.), (Executive Secretary); V. Bakhmutov, Dr. Sci. (Geol.), Senior Researcher; S. Vyzhva, Dr. Sci. (Geol.), Prof.; Z. Vyzhva, Dr. Sci. (Phys.-Math.), Prof.; V. Guliy, Dr. Sci. (Geol.), Prof.; O. Dubyna, Dr. Sci. (Geol.); V. Zagnitko, Dr. Sci. (Geol.-Min.), Prof.; V. Zacerkovniy, Dr. Sci. (Tech.), Prof.; O. Ivanik, Dr. Sci. (Geol.), Prof.; O. Karpenko, Dr. Sci. (Geol.), Prof.; M. Korzhnev, Dr. Sci. (Geol.-Min.), Prof.; I. Korchagin, Dr. Sci. (Phys.-Math.), Senior Researcher; O. Koshliakov, Dr. Sci. (Geol.), Prof.; Prof.; V. Lozitsky, Dr. Sci. (Phys.-Math.), Senior Researcher; B. Maslov, Dr. Sci. (Phys.-Math.), Prof.; O. Mytrokhin, Dr. Sci. (Geol.), Prof.; Prof.; G. Milinevskiy, Dr. Sci. (Phys.-Math.), Senior Researcher; V. Nesterovskiy, Dr. Sci. (Geol.), Prof.; V. Ogar, Dr. Sci. (Geol.), Prof.; M. Orliuk, Dr. Sci. (Geol.), Prof.; O. Shevchenko, Dr. Sci. (Geol.), Senior Researcher.; V. Shevchuk, Dr. Sci. (Geol.-Min.), Prof.; S. Shnyukov, Dr. Sci. (Geol.), Assoc. Prof.; T. Pastushenko, Cand. Sci. (Phil.), Assoc. Prof.; T. Mironchuk, Cand. Sci. (Phil.), Assoc. Prof. Foreign members:

T. Dindaroğlu, Kahramanmaras Sütçü Imam Üniversitesi, Turkey; A. El Albani, Universite de Poitiers, France; O. Ivakhnenko, Kazakh British Technical University, Kazakhstan; A. Koroneos, Aristotle University of Thessaloniki, Greece; Q. Liu, China University of Geosciences, China; M. Olivia, University of Lisbon, Portugal; P. Pereira, Mykolas Romeris University, Lithuania; V. Portnov, Karaganda State Technical University, Kazakhstan; V. Schmidt, Münster University, Germany; S. Spassov, Geophysical Center of Dourbes, Belgium; A. Vesnaver, Italian National Institute of Oceanography and Applied Geophysics, Italy; Q. Zeng, China University of Geosciences, China

Institute of Geology, 90, Vasylkivska Str., Kyiv, 03022, Ukraine, tel. (38044) 43104 40; e-mail: geolvisnyk@ukr.net; http://www.geolvisnyk.univ.kiev.ua

Academic Council of the Institute of Geology June 2, 2021 (Minutes \# 17)

Higher Attestation Board

(the State Commission for Academic Degrees and Titles), Ukraine Edict \# 1-05/6 issued on 12.06.2002

Ministry of Justice of Ukraine

State Certificate \# 23534-13374 issued on 08.08.18

Taras Shevchenko National University of Kyiv, Publishing and Polygraphic Center "Kyiv University", State Certificate \# 1103 issued on 31.10.2002

14, Taras Shevchenka blv., Kiev, 01030, Ukraine ? (38044) 23931 72, 23932 22; Fax 2393128

(C) Taras Shevchenko National University of Kyiv, Publishing and Polygraphic Center "Kyiv University", 2021 


\section{MINERALOGY, GEOCHEMISTRY AND PETROGRAPHY}

Kirin R., Baranov P., Koziakov I.

Gemolocial law of Ukraine: formation problems and development prospects

Splodytel A.

Ecological and geochemical estimation of the spreading of technogenic elements in the territory of Kivertsiv national natural park "Tsumanska Pushcha"

Ivanchenko V., Berozkina L., Stetsenko V., Kovalchuk L.

Schlich mineralogical analysis for research of modern bottom sediments

\section{MINERAL RESOURCES}

Mykhailov V., Kurilo M., Kosharna S.

Geological industrial assessment and ranking of promising objects of the domestic base of rare earth elements

Mansurov M.

Location peculiarities and evolution of Koshkarchay copper-porphyre field (Lesser Caucasus, Azerbaijan).....

Imamverdiyev N., Baba-zadeh V., Mursalov S., Valiyev A., Mansurov M., Ismayilova A.

Prospects of newly discovered Ugur area in the northwest of the Gedabey ore district

(Lesser Caucasus, Azerbaijan).

Kharytonova T., Nosik V., Kostruba A., Mykhailov V., Kurilo M.

The correlation between land and subsoil use when using underground space

\section{HYDROGEOLOGY, ENGINEERING AND ENVIRONMENTAL GEOLOGY}

Shevchenko O., Skorbun A., Osadchiy V., Charny D.

Variable rhythms in groundwater regime and their relationship with climate factors

Lopushnyak V., Hrytsulyak H., Tonkha O., Menshov O., Pikovs'ka O., Sychevs'kyy S.

Content of heavy metals in soils of oil-polluted areas of Pre-Carpathian.

Miedviedieva O., Koshliakova I., Dyniak O.

Hydrochemical condition of groud water within the city of Tatarbunary of Odessa region

\section{GEOLOGICAL INFORMATICS}

Lubkov M., Zaharchuk O.

Modeling of displacement processes in heterogeneous anisotropic gas reservoirs.

Lazorenko-Hevel N., Galius I., Zatserkovnyi V., Denysiuk B., Shudra N.

Specificities of the creation of geoinformation maintenance of the territory

of Chornobyl radio-ecological biosphere reservefor geoinformation monitoring conduction

Getmanets O., Pelikhatyi M.

Self organizing neural maps in the problems of ecological monitoring 
T. Kharytonova, Dr. Sci. (Law), Prof., ORCID iD 0000-0002-7998-5089,

E-mail: haritonova@onua.edu.ua, National University "Odesa Law Academy", 23 Fontanska road, Odesa, 65009 Ukraine; V. Nosik, Dr. Sci. (Law), Prof., ORCID iD 0000-0003-3483-4575, E-mail: vnosik@ukr.net,

Taras Shevchenko National University of Kyiv, Institute of Law, 64/13, Volodymyrska Str., Kyiv, 01601 Ukraine; A. Kostruba, Dr. Sci. (Law), Prof., E-mail: anatolii.kostruba@pnu.edu.ua, Vasyl Stefanyk Precarpathian National University, Ivano-Frankivsk, 57 Shevchenko Str., Ivano-Frankivsk, 76018 Ukraine; V. Mikhailov, Dr. Sci. (Geol.), Prof., E-mail: vladvam@gmail.com;

M. Kurilo, Cand. Sci. (Geol.), Assoc. Prof. E-mail: kurilo@mail.univ.kiev.ua; Taras Shevchenko National University of Kyiv, Institute of Geology, 90 Vasylkivska Str., Kyiv, 03022, Ukraine

\section{THE CORRELATION BETWEEN LAND AND SUBSOIL USE WHEN USING UNDERGROUND SPACE}

(Представлено членом редакційної колегії д-ром геол. наук О.І. Меньшовим)

There is a strong bonding of categories when we are to consider problems connected with land. The constant development of social relations brings the necessity to notice what is vital for the legislation to follow those changes. In that order, there is unambiguity in resolving land disputes, particularly about subsoil use. The spatial use of land rights raises a question of clear legislative criteria for their application. For us, it refers to the consideration of the "upper" and "lower" limits of rights distribution. Accordingly, this article investigates the rules of legislation for land and subsoil use. The object of the study is legal problems arising from social relations regarding land and subsoil use. As for the methodology, the following methods were used: analysis, synthesis, deduction, induction, abstraction, generalization, historical and legal methods, formal-legal (dogmatic) method, comparative-legal and sociological-legal methods, legal modeling, and critical-legal method. It has been concluded that domestic legal doctrine includes two approaches to the distribution of owner's rights for the underground space. Additionally, there is a problem of legal demarcation between land and subsoil use. As a result of the study, we offer some ways to solve this issue.

Keywords: subsoil, subsoil code, land use, property rights, urban planning.

Formulation of the problem. We consider the exploration of property rights to land and subsoil use as such of a great scientific and practical value. This consideration also consists of such aspects as spatial boundaries of the ownership.

It follows, that relationships between owners and other people in this area should have sufficient legal regulation. Per contra, there is no legal definition of delimitation between land and subsoil use. By meaning this, it brings lots of misunderstanding when things get practical. For example, Ukraine's legislation restricts using land to certain spatial boundaries. Likewise, "upper" and "lower" limits have no clear principles and criteria in the law. On the contrary, the distribution of rights to use the airspace has well-established legal regulation in Ukraine, while the boundaries separating land plots from subsoil have no explanation in law. Speaking of the underground construction, it leads to conflicts like those whether a certain landlord has a right for subsoil use. For example, Part 3 of Art. 373 of the Civil Code of Ukraine (2003) (hereinafter - CCU) provides that the ownership of land extends to the surface (soil) layer within the owner's area. It includes water bodies, forests, perennials, as well as the space above and below the surface of the site, height, and depth, which are necessary for the construction of residential, industrial, and other buildings and structures. At the same time, Part 5 of Art. 373 of CCU establishes that the owner can use everything that is above and underground, i.e. below the surface of the soil, unless the law provides otherwise and if it does not violate the rights of others. Then the question arises whether Part 3 and Part 5 of the Art. 373 of CCU are contradictory or not. In this case, we need to look closely at the wording of the law. It follows, that landowners may use everything above and below the surface of the land at their discretion unless otherwise is provided, and if it does not violate the rights of others. This right extends on the land parcel, the airspace above it, the soil, subsoil, etc. From this point of view, it may seem that the right of ownership of land implies the limitless right of the owner to use it, which is not original in domestic law, as there must be certain restrictions from a technical point of view to such use.

The categories of land and subsoil use are of great importance for the domestic doctrine of land law. The reason for this is that they are part of a more general concept of a common natural environment. By stating that, we mean that they are interrelated and play essential environmental and legal role in the field of land and natural resources law. Through land use, we obtain physical access to all subsoil resources such as minerals, gems, stones, water, underground space, etc. But the crucial thing to note here that the ownership of subsoil (and relevant resources) belongs to the people of Ukraine, and landowners may be specific individuals. Except for civil law, current legislation has demarked legal regimes of land and subsoil use. In particular, the law establishes land and subsoil private ownership. However, the current legislation does not provide an opportunity to resolve such conflicts unambiguously. Consequently, it is of great validity to determine the boundaries of the subsoil area usage.

Research methodology. We used general and specific scientific methods for the study. For example, the general methods are analysis, synthesis, deduction, induction, abstraction, and generalization. We should discuss also in more detail the specific methods used in the work, since they were of prominent efficacy during the writing of the essay. Consequently, it should be noted that in the methodological arsenal of jurisprudence there are only a few special methods of cognition regarding the legal reality, namely:

- historical-legal method;

- formal-legal (dogmatic) method; 
- comparative-legal method;

- sociological-legal method;

- as well as the method of legal modeling.

In addition, special attention should be paid to the critical-legal method as the method of legal cognition. Thus, we recall that from a philosophical point of view, criticism is a test of scientific judgment for its truth. Therefore, the term "criticize" means to question the truth of a judgment (in our case - a legal statement).

Scientific criticism is one of the most significant processes of attaining scientific knowledge, which is to verify the compliance of theoretical provisions with the criteria of truth, objectivity, provability, verifiability, and more. The role of critique in its application to new data, ideas, notions, and theories is of distinctive importance.

Knowledge has weight only after it passes the challenges of criticism, remaining convincing, undeniable, and true. All legal theories, principles, and statements must be criticized, proven to be viable, and updated. Therefore, the critical-legal method is often described as such of fundamental value. Therefore, concerning this study, not only contradictory scientific positions are subjected to critical analysis, but also the current legislation, which does not always correspond to modern substances in the field of subsoil and land use.

Analysis of recent research and publications. As the article was in development, various works of both Ukrainian and foreign scientists were analyzed. Those works are devoted to the problems of legal regulation of social relations that are emerging in the fields of subsoil use, land use, and urban planning.

Special attention was paid to the following authors: Chyryk (2019), Dimitriev (2011), Gaiko (2014), Ignatenko (2015), Kalinichenko (2016), Kirin (2017a; 2017b), Kolotinskaya (1986), Kulinych (2011; 2014; 2015), Miroshnichenko (2011), Naumov (1928), Voronina (2008).

Highlighting previously unselected parts of the overall problem. Meanwhile, analyzing domestic and foreign legal doctrine, it is possible to conclude that currently in the literature and legal framework of the state, there is no clear answer to the question of where the "lower" limit of the rights of owners and users of land is, and there is a problem of legal delimitation the concepts of "subsoil use" and "land use". It is these two aspects that determine the relevance of this article.

Setting the goals of the article. The article aims to define a clear distinction between the concepts of "subsoil use" and "land use" and to find an answer to the question of where the "lower" limit of the rights of owners and users to land.

Thus, based on the goals of the study, it seems possible to form the following tasks:

1) to find a solution to the problem of legal delimitation of the concepts of "subsoil use" and "land use";

2 ) to determine the optimal method of delimitation of land plots and subsoil located underground, and;

3 ) to establish the most acceptable legal regime for the use of underground for urban needs.

Research results. It is worth mentioning that the complex issue of establishing boundaries and determining the legal regime of land and scholars have studied subsoil since the XIX century. As a result of such inquiries, the following scientific concepts concerning the decision of the specified question were formed.

The first one is the concept of indivisibility of land and subsoil, meaning land and subsoil have/should have a joint legal regime). Particularly, some authors deny the fundamental possibility of qualifying the subsoil as an independent object of legal definition. Consequently, Kalinichenko (Kalinichenko, 2016) states in his thesis that subsoil legislation does not allow to determine where the boundary between the land and the subsoil is. In her opinion, it is necessary to refuse recognition of the subsoil area as an independent object of the property rights and to include it in the model of the land plot.

Dimitriev (2011) takes a resemblant position. According to him, the subsoil area in its characteristics is nothing but an integral part of the land plot. He also takes the stand that when we discuss the concept of subsoil area, we should not argue about subsoil as a separate object of civil rights, but about the specific real right to use the land plot in terms of minerals contained in its subsoil.

The second approach to the questioned dichotomy is the concept of separation of land and subsoil, meaning land and subsoil have/should have a separate legal regime.

In turn, here appears a call to identify what is the essence of terms, if land and subsoil are separate categories.

It should also be noted, that scientists and lawmakers have no joint opinion on this issue.

In some countries, there is a clear delimitation of the surface of the earth, which we are used to calling "land", and the line from which the subsoil begins. For example, under Polish law, the boundary between the surface and the subsoil runs at a depth of $30 \mathrm{~m}$. The scope of mining legislation and the competence of mining authorities include issues related to the extraction of minerals, their exploration, etc., wherever they occur, as well as the use of the globe's surface for other purposes at a depth of more than $30 \mathrm{~m}$. It can be debated that Polish lawmakers were not pioneers in establishing such a method of differentiating land and subsoil. Consequently, back in 1925, the Venezuelan Mining Law clearly distinguished the concepts of "surface" and "subsoil", meaning the first top layer of earth to a depth of 3 $\mathrm{m}$. It also provided that the owner of the land should not bore deeper than that. In the latter case, the term "surface" is defined, concerning a particular case by the relevant governmental authority for the safety of surface structures. Hence, it is clear, that subsoil begins where the surface ends (Voronina, 2008; Naumov, 1928).

Whereas in contrast, an unambiguous legislative definition of the boundaries of land and subsoil can cause numerous problems associated with the actual impossibility of compliance with these requirements in individual cases. In particular, Navrotska (1976) considers that the upper limit of the subsoil should be considered not just the earth's surface, but the "conditional surface" of the land's territory, bearing in mind the location of the object (autonomous use of the underground environment) and the purpose of the earth's surface. It follows that the boundaries of subsoil and land should be set each time alone, taking into account the specifics of the case.

Therefore, subsoil and land are not just objects that replace each other in space, but objects, each of which takes its place in economic activity. Therefore, relations on the use of subsoil and land differ, above all, in content. It seems that this approach to the delimitation of land and subsoil can be considered as one of the most appropriate.

The use of the underground space can be acknowledged as a continuation of land use, especially when it comes to meeting personal non-commercial demands. This sort of land use can similarly be compared to assuring the right to leisure and recreation. Such practices incorporate all other kinds of general subsoil use other than direct extraction of metals, crystals, gems, etc., from the subsoil. It involves ecological tourism, paleontological objects usage, unique minerals sampling, scientific and educational activities, speleology, mountaineering, etc. 
There is a necessity to examine the problem of establishing the spatial boundaries of land rights in the context of urban planning. In this context, a feasible question emerges: what specific right is acquired by the owner - the property right to use underground space to a certain extent? Alternatively, the right to build underground structures? Consequently, to address these proposals, it is vital to probe in more detail the current legislation on subsoils.

In this way, Art. 4 of the Subsoil Code of Ukraine (1994) establishes that subsoil is the exclusive property of the people of Ukraine and it is provided use-only. Agreements or actions that directly or implicitly violate the ownership of the people of Ukraine in the field of subsoil ownership are invalid. The people of Ukraine exercise their ownership through the Verkhovna Rada of Ukraine, the Verkhovna Rada of the Autonomous Republic of Crimea, and local councils.

The Subsoil Code of Ukraine (Article 14) distinguishes geological examination of subsoil among the varieties of subsoil use, including research and industrial development of mineral deposits of national importance; mining; construction and operation of underground facilities not related to the extraction of minerals, including facilities for underground storage of oil, gas and other substances and materials, disposal of harmful substances and industrial waste, and wastewater discharge; creation of geological territories and objects of important scientific, cultural, sanitary and health significance (scientific landfills, geological reserves, sanctuaries, natural monuments, medical, health facilities, etc.); performance of works (activities) provided in the shared production agreement; meeting other needs.

According to the contemporary national enactment, there are several ways to use the subsoil, among which a special place is occupied by the underground construction. The right to use subterrene cavities as a legal structural component of the right of subsoil use is a system of legal norms governing public relations in the field of extraction of useful properties of underground cavities, their types, procedure, and conditions of design, construction (creation), operation and termination (conservation, liquidation) of use. In some sense, it can be clarified, that we can withdraw underground, or subterranean, law as an integral part of subsoil law, which is also mining and geological law (Kirin, 2017).

Therefore, the foregoing considerations designate that the relationship of land use (on land, above, and underground) is the same and should not be governed by different branches of law. Otherwise, problems and conflicts occur inescapably. As we can witness, there is a broad gap between reality and the law. Outdated conservative legislation focuses on the period when only land resources could be the spatial basis. However, subsoil began to be used for the installation and maintenance of underground structures not associated with the extraction of minerals along with scientific advancements (Kolotinskaya, 1986).

Contemporary scientific development permits solving the above problems with the help of vertical zoning, which will allow not only using the surface space in the planning process but also underground as a geospatial resource. Qualitatively new spatial, aesthetic, and ecological characteristics can be created due to the improvement of "vertical zoning" in multifunctional aspects with the integrated use of underground space as the preconditions for the formation of urban ensembles. Therefore, the advancement of the underground space of megacities should be carried out on the principle of not only "horizontal" but also "vertical" zoning of underground layers (Ignatenko, 2015).
Such activities as "urban planning" and "subsoil use" often go indistinguishable nowadays in Ukraine. This way, it can be argued that this standpoint complicates the rational use of geological resources (Gaiko, 2014). In turn, it would be appropriate to determine what is meant under this concept. In most cases, it is the subsoil and the associated resources. They are objectified to the law. Subsoil resources are considered to be solid, liquid, gaseous minerals, energy resources, and subsoil cavities of natural and artificial origin. Usually, researchers divide them into 6 categories (Rudko et al., 2012):

1. Mineral deposits:

- deposits of solid, liquid, gaseous minerals of homogeneous composition;

- complex deposits of solid, liquid, gaseous minerals, represented by nearby deposits with significantly different material composition. The development of such facilities is carried out jointly with a single system of mine workings, and the processing of extracted minerals of different compositions is carried out separately or according to different technological schemes.

2. Dumps of overburden rocks, heaps of coalmines, and warehouses of off-balance-sheet minerals.

3. Waste from mining, processing, and metallurgical plants.

4. Deep sources of the fresh, mineral, and thermal water.

5. The internal, deep heat of the Earth's subsoil (geothermal resources, i.e. part of the solid, liquid, and gaseous phases of the earth's crust, which can be effectively extracted from the subsoil and used at the actual level of geothermal energy technology).

6. Natural and artificial cavities in the massif of rocks.

Not all subsoil resources are systematically considered as objects of law according to domestic legislation. Traditionally, most legal approaches and methods relate to minerals (their geological study and extraction). The legal regulation of mining tools is less detailed but sufficiently developed for the construction and operation of underground structures, which use not only the subsoil cavities but also such properties of the geological environment as the stability of the massif, favorable engineering, and geological conditions, etc. It is meant, that to consider separately the type of subsoil use for the creation of geological territories and objects of important scientific, cultural, sanitary, and health significance means to acknowledge the association with the satisfaction of intangible human needs. This type of subsoil use can be closely related to the field of land use in cases where geological objects are located on the daylight surface.

It can also be shown that legislative uncertainty regarding the rights to use land and subsoil must be discharged. To be specific, this demand befalls due to the calls of those land and subsoil users who manage the same part of the territory independently for different purposes. However, such use cannot be completely independent as the use of the subsoil area automatically imposes some restrictions on the use of the land plot above it. The use of the subsoil area below imposes restrictions on the use of the subsoil area above (Voronina, 2008).

It is required for the introduction of the vertical zoning model that a rather substantial revision of other theoretical and practical aspects of the regulation of these relations can be legally provided. It is likewise expected of the approach to the legal regime of "non-land real estate" to be rethought in order to define a land plot as a certain part of the space to which the rights of the owner of the surface or certain exclusive rights to use such space apply. There is no necessity also to deny individual ownership to the same part 
of space. As an example, let us imagine that there is a multistory residential building on a communal or state property land plot, which is sometimes considered as a separate real estate with a corresponding certificate, or license, of ownership of developers or other persons to apartments in it. It can be debated that the so-called "tripling" of property rights occurs in this case. The current domestic legislation does not contain unambiguous answers to the issues of the nature of the "spatial rights" of landowners, meaning they are not yet fully substantiated. Therefore, it is crucial to set the spatial boundaries of the rights of landowners and owners of other objects above and below the earth's surface. But how can this be done?

The first option is to ascertain property rights or obligatory relations. If we accept the idea of owner's rights as infinite "up and down", all issues concerning the use of space above and underground could be resolved easily with the help of such civil law tools as servitude, superficies, or other obligation. If such practice is permitted according to the planning documentation, another person may come with the management of these spaces only by agreement with the owner (user) of the land plot. It can be argued that in this particular case, the owner's rights "absorb" this space, hence they are: 1) in the sphere of domination of the owner; 2 ) covered by the regime of this land as real estate. An example is the construction of a multi-story building, which involves the development of underground spaces (laying the foundation, installation of underground parking, underground shopping facilities, etc.).

If terrestrial, above-ground, and underground spaces intend to be used by different persons, the "spatial conflict" can be hypothetically resolved in the sense of landeasement relations. However, here the question of recognition arises: who is the owner and who is the servitude? Consequently, which of the persons was the first to register the right to the relevant land plot? The domestic legislation does not determine which thing (say, an underground structure or an above-ground house) is the "main" object. Furthermore, which object can be considered primary and secondary in the meaning of ownership? It follows, that here lies the principle of the registered owner, which can be translated as "he, who is registered, is the owner". Additionally, it is important to keep in mind the nature of servitude as a limited right that is placed under specific circumstances, for example, when it is unmanageable to satisfy the interests otherwise. An example of negative land servitude is the ban to carry out certain activities on the land, say, to construct buildings above a certain height, etc.

The second option lies in the introduction of new legal constructions. It is argued that the activities of owners and users to the land apply to the expanse located on both sides of the earth's surface and can be ensured as legitimate by the legal structure as follows: "the right to use the space adjacent to the land above and below its surface" (Kulinych, 2011). Herein, underground space can be included in the land plot, and, accordingly, it is "extended" ("distributed") by the right of ownership. The area usage on another, non-proprietary, rights requires supplementary justification in regard to its nature, content, etc., as well as a separate legislative ordinance. If we are to compare "the right to use" to "the right of ownership", it can be argued that the former is considered incomplete. In this case, it is additionally noteworthy to set a demarcation between heterogeneous subsoil resources that fall into the geometrized geological space. The right of landowners and land users to use land and subsoil applies "by default" to the use of the geological environment with its engineering and geological properties. Unlike that, the rights of land users do not include the ability to utilize other subsoil resources (minerals, geothermal resources, etc.).

Finally, it is permissible to suggest the third option, which is the use of a legal mechanism of joint ownership, or management. The right of joint partial ownership of land should be viewed as the right of several persons to own, use and distribute the land as a single object amounting to 1 (unit) with certain shares in the right of joint partial ownership. Firstly, it is certain that other owners are restricted on the rights of co-owners. Secondly, joint partial ownership is contractual. Therefore, these are the demands for possession, usage, and distribution of land in joint partial ownership to occur (Chyryk, 2019). An example is constructing a multi-story residential house with underground parts, where the legal roles of co-owners are distributed consensually under the contract of joint partial ownership or lease. According to Art. 88 of the Land Code of Ukraine (2002), the co-owners of the plot may agree on separate use of its aboveground and underground parts considering the land plot as part of the space. A similar agreement of cotenants of the land plot does not contradict the law as well. It is noteworthy that proposed models are not ideal as it is often hard to delimit the shares of co-owners.

In addition, there may be a circumstance under which the site is transferred for use for the development of a certain area or for the creation of green zones for public utility. The aforementioned does not dismiss the opportunity of conducting the underground construction by another person (underpasses, metro stations, trade facilities, etc.), particularly with the subsequent restoration of the damaged elements of landscaping. It is hard to maintain that the underground space of considerable length falls within the sphere of ownership domination of the land user or landowner to whom the site is provided, or transferred, for landscaping purposes. A significant deepening into the soil is not provided in this case mainly because of the restrictions imposed by the permitted use of the land plot, as well as by the provisions of the planning documentation, and what is usually is not of economic interest to the owner (user).

Nevertheless, the aforementioned problems can have a solution. An example is sharing one land plot in a variety of ways. Let us imagine the construction of a tunnel or other structure at the "foot" of a mountain with houses on its top (whether they are used for gardening or horticulture, etc.). In our opinion, it is not in the interests and dominance of owners on the top of the mountain to prohibit the development of caves or tunnels at its foot if it does not do any harm in the process or perspective for owners good and safety and does not cause any inconveniences in the process. Nonetheless, the owners of "surface plots" could claim damages or collect a fee for a "negative servitude", or even try to ban the relevant activities of the "underground user" by appealing to the principle of "qui est solum...". Notwithstanding, the courts must refuse to satisfy such claims because what happens at the foot of the mountain when there are no specific inconveniences like loud noise, vibration, smoke, etc., is outside the sphere of interest of the landowner. The Greek Constitution provides an example for such a case. It follows, that it allows the possibility of tunnel construction without compensation to the owner of the land in instances where "the tunnel construction will not interfere with the normal use of property located above it" (Chyryk, 2019). This is a restriction on the rights of owners of "surface plots" in social favor, which does not deny but rather confirms that, as a general rule, the underground space 
under the plot belongs to its owner or user. However, this issue still requires further examination.

According to the given domestic legislation, there is a demand for obtaining special permission for the construction and operation of underground structures not related to the extraction of minerals. It has to be approved by relevant district, city, town, village councils, and councils of united territorial communities, as follows from the Procedure for special permits (Resolution..., 2011). Additionally, the kind of economic activity can have its impact on the decision of the authorities whether or not it is appropriate to give such acquiescence. Paragraph 10 of the Regulations on the procedure for granting mining allotments (On approval of the Regulation..., 1995) allows local councils and executive bodies to give permissions on mining allotments under the territory where buildings, structures, settlements, etc., are located.

Article 23 of the Subsoil Code of Ukraine (1994) enshrines the right of landowners and land users to extract minerals of local significance, peat, groundwater (except mineral waters), and use subsoil for other purposes. At the same time, it is restricted for such drilling to go deeper than 2 meters and extract more than up to $300 \mathrm{~m}^{3}$ of groundwater per day. Nonetheless, there is no provision for the details of subsoil use by landowners and land users other than the abovementioned purposes.

Coming closer to the conclusions of the study, it can be stated that there are some flaws in the modern law on boundaries to rights of landowners and land users when underground space usage is taken into consideration. If we are to conclude that each land plot following its purpose can be attributed to only one of the categories of land enshrined in the Land Code of Ukraine, then it essentially impoverishes the legal regulation of land use as part of space. Moreover, it once again proves the inappropriateness of leaving the division of land into a closed list of mutually exclusive categories of land under such law. An additional argument against it is that the use of a certain area involves concomitant and permissible uses that may occur at different levels of space. As an example, we can imagine a rock massif, various parts of which serve different objectives. The underground space is occupied by production, the cavities are used for recreation, and the surface is used for housing. It is not provided by the modern legislation of Ukraine that it is likely for such a plot to be assigned to a clear legal model of regulation with a certain category and purpose. In turn, this uncertainty creates the preconditions for corruption and the use of land with significant violations. It is debatable that in forming land plots as real estate objects according to such principles, we may end up speaking of separate immovable possessions (land plots) in one projection.

Despite the obvious advantages, this progressive approach has notable counterarguments. Consequently, the allocation of individual "spatial land plots" is not fully consistent with the principle of "qui est solum...", which is recognized in many countries, although this principle is hardly anywhere perceived as an absolute. The consistent introduction of this principle has not been fully provided in Ukraine's legislation either. Herein, landowners generally do not have ownership not only of the subsoil but also of the space occupied by the subsoil. In this case, the essence of the subsoil is in its available/given resources. Similarly, there is no question of the likelihood of using an infinite (or even relatively long) airspace over the land. Ukrainian legislation also does not have conditions for accounting lands in various "sections" (i.e., "stratas"), as there is a "two- dimensional" cadastral system. Currently, the development of underground and, in some cases, aboveground spaces often takes place without registration of any documents for land use or subsoil use and, accordingly, with underpayment of land fees. The Subsoil Code states that it is allowed for the construction of mineral deposits of national importance, as well as the construction of non-mining facilities on their sites, to be held in exceptional cases only with the consent of the central executive body, which implements the state policy in the field of geological study and rational use of subsoil, and the central executive body that implements the state policy in the field of labor protection. In reality, this principle is hardly upheld, which leads to material losses and huge risks of destruction in a variety of circumstances.

Here lies a proposal that the best option may be to determine in principle, which is the algorithm of "primary" alienation of use of aboveground and underground spaces of land from the state and communal lands ownership. It can be argued also that it is almost impossible every time in Ukraine to construct some underground object without violating the rights of the existing "surface user". For example, there is nothing new when it occurs that various persons have ownership towards one land, but one of them has ownership to the surface and another has superficies for mining purposes. It follows, that this situation can befall during the preparation of lots for sale of land or rights to them at auctions, so it is tolerable to grant simultaneous use of both aboveground and underground spaces of a certain land plot, which can be purchased by several people, for example, to get a plot for joint lease, joint ownership, etc.

Another problematic issue is the forced "termination" of the legal regime of land in the case of the construction of various real estate objects owned by various entities above and below the ground. The fact is that such events are not directly taken into account in Art. 120 of the Land Code of Ukraine and Art. 377 of the Civil Code of Ukraine (2003), so the practical application of these provisions may be ambiguous. In some cases, there are insufficient grounds to consider such buildings or structures as the main thing and accessories or as part of a single "property complex", as they may be completely separate and unrelated physically and legally immovable things. This is an additional confirmation of the imperfection of the model of "following the building", which is the basis of these rules in land and civil law.

Kulinych (Kulinych, 2015) concluded that the legislation of Ukraine implements the land-centric legal concept of real estate, according to which it can be the land itself and everything that is inextricably linked to it. Underground buildings do not have an inseparable connection with the land, so they "fall out" of the legal concept of real estate. The scientist substantiated the subsoil-centric concept of real estate, according to which the building (structure), which is located underground, has a legal connection not with land, but with subsoil (ibidem). He (Kulinych, 2014) also proposes to combine these concepts in civil and land legislation. The researcher insists on further multiplication of real estate. It is advisable to introduce the concept of a land plot as a single real estate object into domestic legislation, for example, when it comes to the use of land for the construction and maintenance of underground or aboveground linear objects of great length.

Conclusions. Currently, the domestic legislation does not provide a clear answer to the question of delimitation of land and subsoil. At the same time, it recognizes the legal regime of lands and the legal regime of subsoil separately, which causes problems when it comes to law enforcement. It seems desirable to study the legislation of the AngloAmerican legal family in this regard as they have the 
indivisible legal regime of lands and subsoil. It is likely that certain provisions of the legislation of those countries could be adapted and implemented into Ukrainian legislation.

Another significant problem is the interpretation of the category of "subsoil use". In particular, this applies to urban planning. These are cases when construction is carried out under the surface of the land. However, it is not about subsoil, but the use of the land. Recognition of this fact by the legislator would significantly simplify the activities of economic entities and bring the current state of relevant public relations in line with current legislation. It would be useful to identify the subsoil resources that are used. Most often, construction takes place in the absence of deposits of national importance and use of the engineering and geological space, which is associated with a certain land and adjacent areas. The introduction of vertical zoning may be of great use to Ukraine's current legislation. It would allow remarkable changes for land and subsoil use. It also means that urban space would have its benefits like environmental and aesthetic improvement.

Thus, the issue of proper legal regulation of land and subsoil use in Ukraine is relevant and promising. Further research on this topic may concern the simplification of bureaucratic procedures related to land and subsoil use and the granting of more rights to subsoil users. In particular, the draft Subsoil Code is currently being actively discussed, which may include a rule on the possibility of transferring subsoil use rights from one user to another or the possibility of selling a special subsoil use permission from one business entity to another.

References

Chyryk, A. (2019). Common partial ownership of land under the land legislation of Ukraine. Extended abstract of PhD thesis. Kharkiv.

Civil Code of Ukraine. (2003). Retrieved from https://zakon.rada.gov.ua/ laws/show/435-15. [In Ukrainian]
Dimitriev, M.A. (2011). On the question of subsoil areas as objects of civil rights. Russian judge, 12, 17-20. [In Russian]

Gaiko, G.I. (2014). Problems of system planning of underground space of large cities. Bulletin of NTUU "KPI". Mining series, 25, 35-40. [In Ukrainian]

Ignatenko, I.V. (2015). Some legal aspects of complex development of underground space of megacities. Theory and practice of jurisprudence, 2(8), 1-11. Retrieved from http://nbuv.gov.ua/UJRN/tipp_2015_2_14. [In Ukrainian]

Kalinichenko, K.S. (2016). Legal regime of the land plot and the buildings, constructions located on it in Russia and Germany. Extended abstract of PhD thesis. St. Petersburg. [In Russian]

Kirin, R.S. (2017). Problems of object structure of underground construction legal relations: rent aspect. Law and society, 5,112-118. [In Ukrainian]

Kirin, R.S. (2017). The right to use underground cavities: concepts and types. Actual problems of domestic jurisprudence, 1(2), 102-106. [In Ukrainian]

Kolotinskaya, E. N. (1986). Legal bases of natural resource cadastres in the USSR. Moscow: Publishing house Mosk. [In Russian]

Kulinych, P. (2011). Legal problems of protection and use of agricultural lands in Ukraine. Kyiv: Logos. [In Ukrainian]

Kulinych, P. (2014). Problems of improving the legal regime of real estate: land-centric and supracentric concepts. Interdisciplinary humanities studies, 1, 30-35.

Kulinych, P. (2015). Real estate as an object of legal relations: land-centric and supracentric concepts. Journal of Kyiv University of Law, 3, $262-265$.

Land Code of Ukraine. (2002). Retrieved from https://zakon.rada.gov.ua/ laws/show/2768-14\#Text. [In Ukrainian]

Miroshnichenko, A.M. (2011). Land law of Ukraine. Kyiv: Alerta.

Naumov, N. (1928). Mining Law of Venezuela. Mining Journal, 3, 181-183. [In Russian]

Navrotskaya, L.G. (1976). Theoretical issues of legal regulation of mining relations in the USSR. Extended abstract of PhD thesis. Moscow. [In Russian] On approval of the Regulation on the procedure for the provision of mining leases: Resolution 59. (1995). Retrieved from https://zakon.rada.gov.ua/laws/ show/59-95-\%D0\%BF\#Text

Resolution of the On Approval of the Procedure for Issuing Special Permits for Subsoil Use: Resolution 615. (2011). Retrieved from_https://zakon.rada.gov.ua/ laws/show/615-2011-\%D0\%BF?lang=uk\#Text

Rudko, G., Mirgorodsky, A., Kurylo, M., Lagoda, A. (2012). Normative legal regulation of subsoil use K.: Hyperion.

Subsoil Code of Ukraine. (1994). Retrieved from https://zakon.rada.gov.ua/ laws/show/132/94-\%D0\%B2\%D1\%80\#Text. [In Ukrainian]

Voronina, A.A. (2008). Delineation of land and subsoil as independent types of natural resources. Actual problems of Russian law, 2, 106-112. Retrieved from https://cyberleninka.ru/article/n/razgranichenie-zemli-i-nedrkak-samostoyatelnyh-vidov-prirodnyh-resursov. [In Russian]

Надійшла до редколегії 14.12.2020

T. Харитонова, д-р юрид. наук, проф.,

ORCID iD 0000-0002-7998-5089;

E-mail: haritonova@onua.edu.ua,

Національний університет "Одеська юридична академія",

Фонтанська дорога, 23, м. Одеса, 65009 Україна;

В. Носік, д-р юрид. наук, проф.

ORCID iD 0000-0003-3483-4575;

E-mail: vnosik@ukr.net,

Київський національний університет імені Тараса Шевченка, Інститут права,

вул. Володимирська, 64/13, Київ, 01601 Україна;

А. Коструба, д-р юрид. наук, проф.,

E-mail: haritonova@onua.edu.ua;

Прикарпатський національний університет імені Василя Стефаника,

вул. Шевченка, 57, м. Івано-Франківськ, 76018 Україна;

В. Михайлов, д-р геол. наук, проф.,

E-mail: vladvam@gmail.com;

М. Курило, канд. геол. наук, доц.

E-mail: kurilo@mail.univ.kiev.ua;

Київський національний університет імені Тараса Шевченка,

ННІ "Інститут геології", вул. Васильківська, 90, м. Київ, 03022, Україна

\section{СПІВВІДНОШЕННЯ КАТЕГОРІЙ "НАДРОКОРИСТУВАННЯ" I "ЗЕМЛЕКОРИСТУВАННЯ" ПРИ ВИКОРИСТАННІ ПІДЗЕМНОГО ПРОСТОРУ}

Нерозривний зв'язок землі та надр зумовлює необхідність адекватної правової регламентації відповідних суспільних відносин, які формуються з приводу використання цих об'єктів. За чинним законодавством питання розмежування земельної ділянки і надр під нею не може бути вирішено однозначно. Зокрема, вітчизняне законодавство обмежує використання земель певними просторовими межами, але чітких принципів і критеріїв цього обмеження в законі немає. Йдеться про "верхню" та "нижню" межі поширення прав власників і користувачів на земельні ділянки. Предметом дослідження виступили норми законодавства з питання регламентації відносин, що виникають на стику надрокористування і землекористування. Об'єкт дослідження - проблемні аспекти суспільних відносин у сфері надрокористування і землекористування. Методологію роботи склали такі методи наукового пізнання: метод аналізу, метод синтезу, метод дедукиії, метод індукиії, метод абстрагування, метод узагальнення, історико-правовий метод, формально-правовий (догматичний) метод, порівняльно-правовий метод, соціологічно-правовий метод, метод правового моделювання, критично-правовий метод. У результаті дослідження автори дійшли висновку, що у вітчизняній доктрині існують два основні підходи щодо поширення прав власника на простір під земельною ділянкою. Також законодавець не дав відповідь на запитання, де закінчується землекористування та починається надрокористування. У роботі визначено варіанти вирішення цієї проблеми.

Ключові слова: надра, кодекс про надра, землекористування, право власності, містобудівництво. 
Т. Харитонова, д-р юрид. наук, проф.,

ORCID iD 0000-0002-7998-5089;

E-mail: haritonova@onua.edu.ua,

Национальный университет "Одесская юридическая академия",

Фонтанская дорога, 23, г. Одесса, 65009 Украина;

B. Носік, д-р юрид. наук, проф.,

ORCID iD 0000-0003-3483-4575;

E-mail: vnosik@ukr.net,

Киевский национальный университет имени Тараса Шевченко, Институт права,

ул. Владимирская, 64/13, Киев, 01601 Украина;

А. Коструба, д-р юрид. наук, проф.,

E-mail: haritonova@onua.edu.ua;

Прикарпатский национальный университет имени Васыля Стефаника,

ул. Шевченко, 57, г. Ивано-Франковск, 76018 Украина;

В. Михайлов, д-р геол. наук, проф.

E-mail: vladvam@gmail.com;

М. Курило, канд. геол. наук, доц.

E-mail: kurilo@mail.univ.kiev.ua;

Киевский национальный университет имени Тараса Шевченко,

уни "Институт геологии", ул. Васильковская, 90, г. Киев, 03022, Украина

\section{СООТНОШЕНИЯ КАТЕГОРИЙ "НЕДРОПОЛЬЗОВАНИЕ" И "ЗЕМЛЕПОЛЬЗОВАНИЕ" ПРИ ИСПОЛЬЗОВАНИИ ПОДЗЕМНОГО ПРОСТРАНСТВА}

Неразрывная связь земли и недр обусловливает необходимость адекватной правовой регламентации соответствующих общественных отношений, которые формируются по поводу использования этих объектов. По действующему законодательству вопрос разграничения земельного участка $u$ недр под ней не может быть решен однозначно. $B$ частности, отечественное законодательство ограничивает использование земель определенными пространственными границами, но четких принципов и критериев этого ограничения в законе нет. Речь идет о "верхней" и "нижней" границе распространения прав собственников и пользователей на земельные участки. Предметом исследования выступили нормы законодательства по вопросу регламентации отношений, возникающих на стыке недропользования и землепользования. Объектом исследования выступили проблемные аспекты общественных отношений в сфере недропользования и землепользования. Методологию работы составили следующие методы научного познания: метод анализа, метод синтеза, метод дедукции, метод индукции, метод абстрагирования, метод обобщения, историко-правовой метод, фоормально-правовой (догматический) метод, сравнительно-правовой метод, социологически-правовой метод, метод правового моделирования, критически-правовой метод. В результате исследования авторы пришли к выводу, что в отечественной доктрине существуют два основных подхода по распространению прав собственника на пространство под земельным участком. Также законодатель не дал ответ на вопрос, где заканчивается землепользование и начинается недропользование. В работе определены варианты решения этой проблемы.

Ключевые слова: недра, кодекс о недрах, землепользование, право собственности, градостроительство. 


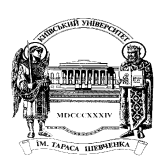

\section{ВIСНИК}

\section{КИЇВСЬКОГО НАЦІОНАЛЬНОГО УНІВЕРСИТЕТУ IМЕНI ТАРАСА ШЕВЧЕНКА}

\section{ГЕОЛОГІЯ}

\section{Випуск 2(93)}

Комп'ютерна обробка статей - О. О. Козіонова

Оригінал-макет виготовлено Видавничо-поліграфічним центром "Київський університет"

Opinions, statements, accuracy of the quotations, economic and statistical data, terminology, proper names and other information are made on the responsibility of the authors. The Editorial Board reserves the right to shorten and edit the submitted materials.

Автори опублікованих матеріалів несуть повну відповідальність за підбір, точність наведених фактів, цитат, економіко-статистичних даних, відповідної галузевої термінології, власних імен та інших відомостей. Редколегія залишає за собою право скорочувати та редагувати подані матеріали.

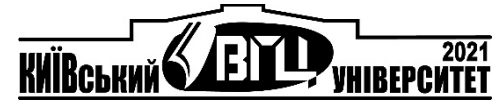

Формат 60х84 1/8. Ум. друк. арк. 13,72. Наклад 300. Зам. № 221-10117.

Гарнітура Arial. Папір офсетний. Друк офсетний. Вид. № Гл2. Підписано до друку 30.06.2021

Видавець і виготовлювач ВПЦ "Київський університет"

Б-р Тараса Шевченка 14, м. Київ, 01030

(38044) 23932 22; (38044) 23931 72; тел./ракс (38044) 2393128

E-mail: vpc_div.chief@univ.net.ua; redaktor@univ.net.ua

http: vpc.knu.ua

Свідоцтво суб'єкта видавничої справи ДК № 1103 від 31.10.02 